\title{
A (re)construção dos referentes em memes verbo-visuais
}

\author{
The (re)construction of referents in visual-verb memes
}

\author{
João Paulo Muniz da Silva ${ }^{1}$ \\ Suzana Leite Cortez ${ }^{2}$
}

\begin{abstract}
Resumo: Pesquisas atuais em Linguística Textual têm destacado a relevância do estudo de textos compostos por múltiplas linguagens para a revisão e alargamento de categorias teóricas dessa disciplina, que historicamente construiu seu aparato explicativo a partir de textos exclusivamente verbais. Tomando isso em consideração e colocando foco sobre os processos de referenciação, este artigo tem por objetivo discutir os modos de (re)construção9 dos referentes em memes verbo-visuais. Seguindo uma perspectiva sociocognitivo-discursiva de texto e referenciação (CUSTÓDIO FILHO, 2011; CAVALCANTE, 2011; CAVALCANTE; CUSTÓDIO FILHO; BRITO, 2014), analisam-se os processos de introdução referencial e anáfora em dois exemplares de memes verbo-visuais coletados do site de redes sociais Instagram. Ao final do estudo, compreende-se que, nesses tipos de meme, os referentes tendem a ser (re)construídos de modo dinâmico, não linear e que sua estrutura composicional resguarda intrínseca relação com esse processo.
\end{abstract}

Palavras-chave: Referenciação. Introdução referencial. Anáfora. Meme.

Abstract: Current research in Textual Linguistics has highlighted the relevance of the study texts composed of multiple languages for the revision and broadening of theoretical categories of this discipline, whitch historically built its explanatory apparatus from exclusively verbal texts. Taking this into consideration and focusing on the referencing processes, this paper aims to discuss the ways of (re)construction of referents in visual-verb memes. Following a sociocognitive-discursive perspective of text and referencing (CUSTÓDIO FILHO, 2011; CAVALCANTE, 2011; CAVALCANTE; CUSTÓDIO FILHO; BRITO, 2014), the processes of referential introduction and anaphora was analyzed in two copies of visual-verb memes collected from the Instagram social networking site. At the end of this study, it is understood that, in these types of memes, the referents tend to be (re)constructed dynamically, non-linear way and that their compositional structure preserves an intrinsic relationship with this process.

Keywords: Referencing. Referential introduction. Anaphora. Meme.

\footnotetext{
${ }^{1}$ Universidade Federal de Pernambuco, Centro de Artes e Comunicação, Departamento de Letras, Programa de Pós-Graduação em Letras, Recife, PE, Brasil. Endereço eletrônico: jotape_muniz@outlook.com.

${ }^{2}$ Universidade Federal de Pernambuco, Centro de Artes e Comunicação, Departamento de Letras, Programa de Pós-Graduação em Letras, Recife, PE, Brasil. Endereço eletrônico: sucortez@ gmail.com.
} 


\section{Introdução}

Como se sabe, os estudos de Mondada (2002[1995]) tiveram grande repercussão para o tratamento da referência, contribuindo para consolidar o entendimento de que a relação entre linguagem e realidade não se dá simplesmente na referência direta e objetiva entre palavra/expressão e objeto do mundo, ou seja, de modo ontológico e referencialista, mas a partir do que a autora concebeu naquela época como referenciação, isto é, um processo de ordem sociocognitivo-discursiva por meio do qual são construídas entidades (objetos de discurso) que (re)elaboram a realidade no momento de interação entre sujeitos/locutores.

Admitindo esse pressuposto, a Linguística Textual (LT) reservou e tem reservado um espaço importante e profícuo aos estudos desse fenômeno. No Brasil, em especial, desde os trabalhos percussores de Ingedore Koch e Luiz Antônio Marcuschi, que acentuaram a importância desse fenômeno para a construção dos sentidos do texto e da tessitura textual, até as mais recentes, que, considerando os importantes postulados desses autores, têm buscado ampliar o seu escopo teórico-analítico ao observar o fenômeno em sua complexidade constitutiva e, inclusive, a partir de sua construção em textos multissemióticos (CAVALCANTE, 2011; CUSTÓDIO FILHO, 2011; CAVALCANTE; CUSTÓDIO FILHO; BRITO, 2014; MATOS, 2018).

O interesse pela investigação da natureza multissemiótica dos textos é uma solicitação que vem sendo feita por diversos estudiosos da LT (CAVALCANTE; CUSTÓDIO FILHO, 2010; CUSTÓDIO FILHO, 2011; CAPISTRANO JÚNIOR, 2012; LIMA, 2017) que têm assumido o texto para além do horizonte linguístico/verbocêntrico, enquanto unidade de sentido que ocorre singularmente em contexto de enunciação, podendo ser construído a partir de diversas semioses (CAVALCANTE et al., 2019). Por meio desta preocupação, estes autores consideram relevante o trabalho de revisitação e alargamento de categorias de análise desse campo científico que por muito tempo dedicou-se a textos exclusivamente verbais. Dentre estas categorias, citamos como relevante e atual a referenciação ${ }^{3}$.

Compreendendo a vitalidade dessas discussões e visando a contribuir, ainda que minimamente, com tal discussão, propomos, neste trabalho, focalizar o processo de referenciação em memes verbo-visuais para compreender como se dá o processo de (re)construção dos objetos de discurso (referentes) nesses textos. Por meio de uma análise quali-interpretativa, discutimos os modos de homologação dos referentes em memes

\footnotetext{
${ }^{3}$ Outras categorias de análise podem ser citadas como a intertextualidade (CARVALHO, 2018) e o tópico (SÁ, 2018). Estes trabalhos de tese foram desenvolvidos no âmbito do Protexto (UFC) e podem ser encontrados no repositório de teses da UFC [http://www.repositorio.ufc.br/].
} 
(introdução referencial) e os modos como esses referentes são (re)categorizados (anáfora) em dois memes verbo-visuais coletados do site de rede social Instagram.

Como subsídio teórico, recorremos à orientação sociocognitivo-discursiva dos estudos desenvolvidos no campo da Linguística Textual, entendendo o texto como "uma unidade singular da coerência textual no contexto da enunciação" (CAVALCANTE et al. 2019, p. 26) e referenciação como o processo de "construção sociocognitivo-discursiva de objetos de discurso reveladores de versões da realidade estabelecidos mediante processos de negociação" (CAVALCANTE; CUSTÓDIO FILHO; BRITO, 2014, p. 41-42).

Retoricamente, este estudo está organizado em três partes principais. Na primeira, discutimos sobre os conceitos de meme a partir de Dawkins (1974), Barros (2016), Lima Neto (2014) e Cavalcante e Oliveira (2019) para depois caracterizarmos o que entendemos por memes verbo-visuais. Na segunda, refletimos sobre os processos de referenciação a partir da perspectiva sociocognitivo-discursiva, tomando como base principal os estudos de Cavalcante (2011), Custódio Filho (2011) e Cavalcante, Custódio Filho e Brito (2014). Já a terceira seção, dedicamos à análise do corpus selecionado. Por fim, apresentarmos as conclusões do trabalho.

\section{Memes verbo-visuais: discutindo conceitos, caracterizando o objeto}

Nas últimas décadas, com a popularização da internet e, principalmente, dos sites/ferramentas de redes sociais, textos com novas e diversas configurações têm surgido. Alguns deles, comumente chamados de memes, têm despertado interesse em pesquisadores da comunicação e, especialmente, dos estudiosos da linguagem, preocupados com a interação, produção textual e a construção de sentidos nesses espaços.

Definir certamente o que é um meme é uma tarefa complicada, pois não há consensos teóricos sobre o que possa designar - um fenômeno sociocultural? Um possível gênero discursivo? Uma prática linguageira comum dos novos meios de interação? Não se pode afirmar com certeza. Assim, buscar uma definição mais sólida de meme, apesar de ser um caminho aberto para pesquisas, não é nosso intuito. Resguardamo-nos a discutir o que se tem dito sobre memes e caracterizar o objeto que compõe nosso corpus de análise, o que optamos denominar, por ora, de meme verbo-visual ${ }^{4}$.

\footnotetext{
${ }^{4}$ A escolha por essa denominação cumpre tão somente a função de identificar os critérios composicionais dos memes que selecionamos para análise neste estudo, uma vez que esses textos podem se manifestar, em sites de redes sociais, a partir de elementos cotextuais diversos, sejam de ordem verbal, imagética, sonora ou conjugando essas diversas semioses. Isso será discutido melhor no decorrer desta seção.
} 
A palavra meme é resultado da abreviação de mimeme, palavra do inglês derivada do termo grego mímesis, que significa imitação. Essa abreviação foi elaborada pelo zoólogo britânico Richard Dawkins, em seu livro O gene egoísta (2007 [1976]). Para o autor, o processo evolutivo não se daria apenas por meio dos genes - unidades responsáveis pela replicação de informação genética dos seres - mas também por outra unidade que, diferentemente do gene, seria responsável pela transmissão de informações culturais. Esta unidade foi nomeada de meme. Lima Neto resume de modo claro essa relação gene-meme discutida por Dawkins:

Se os genes são replicadores biológicos, informações codificadas por suas cópias, ou seja, são eles que se perpetuam no tempo, sendo os elementos mais favorecidos pela seleção natural, os memes são replicadores culturais: são ideias, unidades culturais de imitação que também são replicadas e perpetuam no tempo. (LIMA NETO, 2014, p. 111, grifos nossos)

A partir desse pensamento, sendo os memes unidades culturais de imitação, diríamos que modos de vestir, hábitos alimentares, gírias, provérbios, músicas e quaisquer outros elementos/assuntos/coisas poderiam configurar um meme, desde que fossem passíveis à repetição por membros de uma comunidade.

Tão logo se popularizou o uso da internet, associou-se à ideia de meme o processo de "viralização" que, no senso comum, diz respeito ao efeito de compartilhamento em massa de determinadas materialidades (posts), propiciado pelas ferramentas digitais, principalmente os sites de redes sociais ${ }^{5}$ (Twitter, Instagram, Facebook e WhatsApp, por exemplo) que permitem um usuário "postar” determinado conteúdo (músicas, notícias, vídeos, etc.) em seu perfil ou conta e ainda que o mesmo seja repostado ou compartilhado por milhares de outros usuários de todo o mundo. Quando ocorre, em uma rede social, esse processo de compartilhamento de conteúdo em massa, diz-se que houve uma "viralização".

A título de exemplo desse processo, podemos citar uma reportagem ${ }^{6}$ feita por uma rede de TV brasileira em 2017, na qual um indivíduo detido pela polícia e nitidamente bêbado responde a todas as indagações da repórter com as seguintes falas: "nunca nem vi" e "que dia foi isso?". Por seu teor humorístico, a reportagem viralizou nos meios digitais e fez com que diversos outros textos relacionados a ela fossem produzidos, publicados e compartilhados nas

\footnotetext{
${ }^{5}$ Compreendemos redes sociais conforme Recuero (2006, p. 25, grifos da autora), para quem "uma rede social é definida como um conjunto de dois elementos: os atores (pessoas, instituições ou grupos; o nós da rede) e suas conexões (interações ou lações sociais)". Nesse sentido, sites como o Facebook são apenas ferramentas do ciberespaço que possibilitam a "formação, mediação e manutenção de redes sociais" (PIMENTEL, 2014, p. 14).

${ }^{6}$ Disponível em: https://www.youtube.com/watch?v=xieg1D077Fs. Acesso em 10 de jan de 2020.
} 
redes sociais. Abaixo, segue uma sequência de três textos, que consideramos memes ${ }^{7}$, produzidos a partir da reportagem viralizada:

Figura 1 - Sequência de memes "que dia foi isso?"

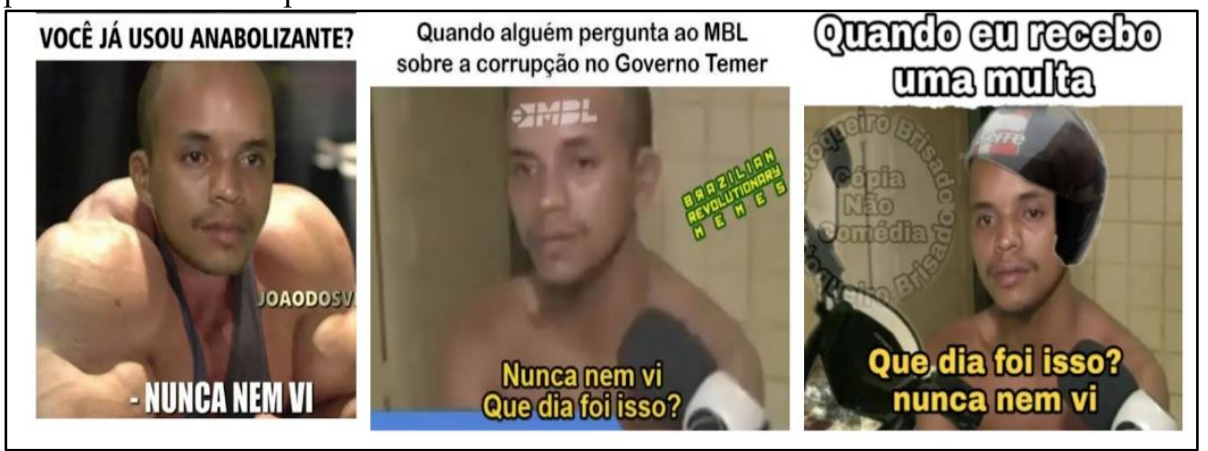

Fonte: http://www.museudememes.com.br/sermons/nunca-nem-vi/. Acesso em 10 de jan. de 2019.

Como se pode ver, os textos tratam de temas diferentes (uso de anabolizantes; corrupção; multa de trânsito), mas retomam imagens comuns e a fala original da reportagem viralizada "Nunca nem vi. Que dia foi isso", estabelecendo, assim, uma relação intertextual com a reportagem e demais textos que retomam o evento. É nesse processo, fundamentalmente intertextual (CAVANCANTE; OLIVEIRA, 2019) que se constituem os memes em ambientes digitais.

No entanto, no senso comum, principalmente para sujeitos usuários de redes sociais digitais, o termo meme passou a ser uma "nomenclatura coringa" capaz de recobrir um grande número de textos e gêneros produzidos em contexto virtual que apresentassem caráter satíricohumorístico, semelhantes a esses que apresentamos.

Sobre isso, muito bem discute Lima Neto (2014) em um estudo sobre a emergência de gêneros no site de redes sociais Facebook. No trabalho, o autor elaborou questionários direcionados a usuários do site, nos quais apresentava diversos textos (possíveis gêneros emergentes) e indagava qual a nomenclatura adequada para cada um deles - dentre outras perguntas. Em resposta, Lima Neto percebeu que o termo meme apareceu como nomeação adequada para vários dos possíveis gêneros apresentados. Dentre as características comuns aos textos considerados memes pelos respondedores, destacam-se as seguintes: organização narrativa em quadros, composição verbo-visual, viés crítico humorístico, uso de editor de imagens (para a produção), recurso a estratégias intertextuais, propagação por meio de links, remix (processo de mescla de gêneros) e abordagem temática de eventos cotidianos.

\footnotetext{
${ }^{7}$ Como já mencionado, é importante salientar que não há um consenso teórico acerca da conceituação de meme. Discutiremos mais sobre isso e retomaremos a noção de memes verbo-visuais mais à frente.
} 
Mediante esse conjunto de características comuns apontadas por vários usuários da rede, poder-se-ia, talvez, dizer que os memes configurariam um gênero digital. $\mathrm{E}$ de fato, diversas pesquisas seguem essa premissa, assim como a de Barros (2016), que retoma as características apontadas por Lima Neto (2014), bem como os dados propostos por Pimentel (2014), para afirmar que exemplares desse "gênero" emergem como "empreendimentos linguísticos" respondendo às demandas sociodiscursivas de interação em redes. Para Barros (2016), seriam eles compostos a partir da junção de fotos, imagens e sequências verbais servindo, comumente, a propósitos humorísticos. Além disso, abordariam temas do contexto social contemporâneo a sua produção e estariam sujeitos à replicação por meio dos compartilhamentos possibilitados pelas redes. Os exemplos que mencionamos anteriormente (figura 1) exemplificariam uma das diversas formas textuais que a autora apresenta como meme.

No entanto, Lima Neto (2014) pondera sobre esse status de gênero muito atribuído aos memes, tanto no senso comum, como em pesquisas científicas. $\mathrm{O}$ autor julga ser mais coerente dizer que o termo aparece como uma nomenclatura para diversos artefatos semióticos veiculados nas redes sociais, os quais não configurariam um único gênero, mas diversos gêneros em situação de emergência ${ }^{8}$.

Esse pensamento é compartilhado por Cavalcante e Oliveira (2019), que definem meme como uma prática linguageira recorrente em diversos padrões de gênero, tomando como pressuposto a noção clássica de gêneros de discurso9 ${ }^{9}$ proposta por Michail Bakhtin (2003). Segundo os autores:

Tendo em vista a diversidade não só de temáticas, mas também de recursos linguísticos (correspondentes à noção de estilo bakhtiniano) e de formas de composições textuais, cremos que, quando falamos em memes, estamos, na verdade, nos reportando a uma rica e multifacetada prática linguageira digital, que, por meio da viralização e da intertextualidade, assume proporções gigantescas e imprevisíveis na construção de sentidos. (CAVALCANTE e OLIVEIRA, 2019, p. 21)

Essa concepção de meme alinha-se com as ideias de Dawkins (1974), apresentadas anteriormente, uma vez que não enfocam a materialidade dos memes, mas o fenômeno de repetição e replicação em si. Desse modo, distingue-se de concepções que restringem os memes a moldes composicionais específicos, "genéricos". Segundo os autores, os critérios essenciais

\footnotetext{
${ }^{8}$ Ainda segundo Lima Neto (2014), a emergência é o estágio no qual não é possível identificar totalmente os aspectos de tipificação de determinada prática discursiva, os quais indiciam e configuram um gênero discursivo como tal.

${ }^{9}$ Como se sabe, para Bakhtin (2003), gêneros discursivos são tipos de enunciados relativamente estáveis, configurados e definidos a partir de regularidades temáticas, estilísticas e composicionais.
} 
de identificação de um meme são a viralização de conteúdos (imagem, frases, sons, vídeos, etc.) e a intertextualidade, que se constitui nesse processo de viralização por meio do qual um texto apreciado pelos usuários passa a gerar diversos outros que nele se ancoram. Nessa esteira, para Cavalcante e Oliveira (2019, p. 17), “faz-se necessário pensar o meme não como um texto apenas, mas como um conjunto de textos (em diferentes gêneros discursivos) que tem como origem um texto-fonte, aquele que dá início à viralização".

Nesse sentido, a partir de tudo o que discutimos até aqui, é possível notar que a noção de meme ainda não apresenta consenso no espaço teórico, apesar de ser tomado de modo muito simples pela comunidade discursiva que utiliza os sites de redes sociais. Não faz parte de nossos objetivos propor uma definição que explique de forma mais abrangente todas as materialidades e/ou fenômenos e/ou processos que são concebidos como memes. Apesar de percebermos a pertinência de tal discussão, restringimo-nos somente a destacar, mediante o que discutimos, a necessidade de ponderação ao se classificar memes unicamente como gêneros ou somente como um fenômeno. Parece-nos que há mais pontos de diálogo entre as perspectivas do que diferenças, por isso o debate parece apenas ter se iniciado.

Desse modo, destacamos que, neste trabalho, tomamos como norteadora a noção proposta por Cavalcante e Oliveira (2019) por ser, ao nosso ver, mais abrangente, uma vez que não restringe a definição de meme a elementos composicionais específicos recorrentes em textos no meio digital, mas o concebe, em observância a sua complexidade, enquanto prática linguageira que recorre em diversos padrões de gênero presentes no ciberespaço, tendo como traços essenciais a natureza intertextual e o efeito viral (de grande replicação).

Sabendo disso e levando em consideração as diversas formas que podem se manifestar nas redes sociais, optamos por considerar para este trabalho apenas os memes que: (a) se constituam a partir das semioses imagética e verbal; (b) não se configurem como um gênero já estandardizado $^{10}$; (c) abordem temáticas de amplo interesse (o que garante um efeito de viralização) e (d) estabeleçam algum tipo de relação intertextual com outro(s) texto(s). Chamaremos os memes enquadrados nessa classificação de verbo-visuais. A sequência de textos da figura 1 ilustra uma forma possível desse tipo de meme.

Assim, tendo apresentado um breve resumo do que se tem discutido sobre os memes no contexto digital, passamos a discutir sobre o fenômeno textual-discursivo que nos chama atenção nesses textos: a referenciação.

\footnotetext{
${ }^{10}$ Lima Neto (2014) aponta que a estandardização diz respeito ao estágio no qual os aspectos sociorretóricos de um gênero encontram-se (relativamente) estabilizados, possibilitando o reconhecimento de seus traços composicionais, temáticos e seus propósitos comunicativos pela comunidade discursiva na qual circula.
} 


\section{Sobre os processos de referenciação}

Quando falamos em referenciação, falamos de um processo dinâmico e complexo pelo qual reconstruímos, no âmbito cognitivo-discursivo, realidades através da linguagem. Essa concepção - a que se admite pela LT - advém dos estudos de Mondada e Dubois (2003 [1995]) para quem a referenciação é um processo dinâmico de "construção de objetos cognitivos e discursivos na intersubjetividade das negociações, das modificações, das ratificações, de concepções individuais e públicas do mundo.” (p. 20). Em outras palavras, não referimos, por meio da linguagem, a objetos concretos de uma realidade pré-existente, mas a objetos de discursos que emergem no universo textual-discursivo, resultantes das negociações de sentidos ocorridas na interação. Considerar isso, como indica Marcuschi (2003, p. 255), "não se trata de negar o valor referencial da língua e sim de rever a maneira como se dá esse processo de referenciação. O sujeito não é apenas enunciativo e sim também social e nesta ação social situada ele instaura e diz o mundo". Para o autor, "a referenciação é uma ação interativa, construtiva e não representacional, possivelmente componencial, que fornece pistas de acesso para elaboração de sentidos” (p. 260).

Dessa forma, esse modo de ver a referenciação distancia-se de uma visão referencialista e vericondicional da linguagem, que a compreende apenas como uma ferramenta de designação e denotação dos objetos de mundo dispostos em uma realidade objetiva/empírica. Como bem salienta Custódio Filho, em referência a Mondada e Dubois (2003 [1995]), "a proposta das autoras sedimenta a posição, marcadamente sociocognitivista, de que os usos linguísticos revelam não a realidade, mas, sim, uma percepção do real” (CUSTÓDIO FILHO, 2011, p. 112).

Nas palavras de Cavalcante, Custódio Filho e Brito (2014, p. 41), a referenciação é um processo de "construção sociocognitivo-discursiva de objetos de discurso reveladores de versões da realidade e estabelecidos mediante processos de negociação.”. Nos estudos da LT, a referenciação é, conforme postulam esses autores, tomada a partir de três processos ou categorias principais: a introdução referencial, a anáfora e a dêixis, que dizem respeito ao tratamento dos referentes no universo textual-discursivo: os modos como são instaurados, homologados, retomados e (re)categorizados ao longo do texto. Neste trabalho, discorreremos apenas sobre a introdução referencial e a anáfora, uma vez que é em torno desses dois processos que incidem nossos objetivos.

A introdução referencial diz respeito ao processo pelo qual um referente aparece pela primeira vez no texto. O modo mais clássico de introdução é através de uma expressão referencial, que é "uma estrutura linguística utilizada para marcar formalmente, na superfície do texto [...] a representação de um referente" (CAVALCANTE; CUSTÓDIO FILHO; BRITO, 
2014, p. 28). Mas um referente pode, também, ser introduzido no universo textual através de outros elementos. Em textos que mobilizam outras semioses além da verbal, um referente pode ser homologado por imagens, sons, gestos etc. Observe-se o exemplo abaixo:

Figura 2 - Tá vendo aquela floresta...

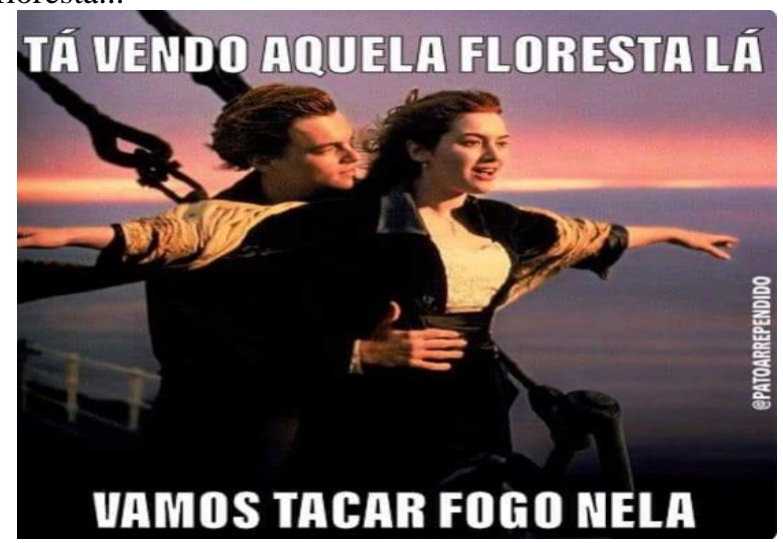

Fonte: https://twitter.com/jorgedesignerbr/status/1200581524229382144/photo/1. Acesso em 01 de dez. de 2019.

Nesse meme verbo-visual, ocorre introdução de referentes tanto pela semiose verbal quanto pela visual. O texto, produzido em novembro de 2019, aborda, de forma satírica, um pronunciamento do então presidente da república, Jair Bolsonaro, por meio do qual o exdeputado atribuiu ao ator Leonardo Di Caprio a responsabilidade pelos incêndios ocorridos na floresta amazônica, naquele mesmo ano. O episódio, considerado esdrúxulo por ser empiricamente infundado, repercutiu nas mídias sociais gerando produções semelhantes a esse meme.

Através da expressão referencial "aquela floresta lá", que também marca uma relação dêitica, homologa-se no texto o referente "floresta amazônica", o qual solicita do interlocutor a retomada de alguns conhecimentos e inferências para que seja efetivamente construído. Além dele, outros dois referentes são introduzidos no texto: "Jack" e "Rose", personagens da famosa produção cinematográfica "Titanic", interpretados pelos atores Leonardo DiCaprio e Kate Winslet. Diferentemente do que ocorre em "floresta amazônica", esses referentes não são introduzidos por meio de expressões referenciais, mas pela semiose imagética que compõe parte do texto.

Cumpre dizer, ainda, que outro referente emerge nesse meme, porém de um modo mais implícito do que ocorre com os demais já apresentados. O referente "incêndios na Amazônia" é engatilhado através sintagma "tacar fogo", expressão que não funciona como elemento de introdução referencial, mas atua como uma pista linguística que, ao solicitar do interlocutor conhecimentos sobre o desastre ambiental ocorrido no Brasil, possibilita a homologação desse novo referente no universo textual-discursivo do meme. 
Esses diferentes modos de introdução referencial, que não se limitam às margens da unidade linguística, salientam a necessidade de observação do fenômeno em sua complexidade de manifestação, considerando os diversos elementos (semióticos, de ordem cognitiva, discursiva, etc.) que concorrem para a construção dos referentes, como tem defendido Custódio Filho (2011).

Ademais, é importante salientar que, conforme Cavalcante, Custódio Filho e Brito (2014) citando Silva (2013), a introdução referencial pode servir a diversas funções além de simplesmente introduzir um objeto de discurso no texto. Dentre elas, a de marcar uma relação intertextual. E isso ocorre no exemplo anterior. A introdução dos referentes Rose e Jack, homologados através da parte visual do texto, estabelece uma alusão estrita (CARVALHO, 2018) com o filme Titanic. Essa relação intertextual é muito importante para a construção dos sentidos desse meme, bem como do efeito cômico-satírico que apresenta.

Mas não só da introdução referencial se faz a referenciação. Quando referentes já introduzidos são retomados ao longo do texto, seja a partir de expressões referenciais ou não, ocorre o processo de anáfora. Essas retomadas anafóricas são importantes para a manutenção da referência (progressão referencial) e da progressão tópica do texto, tornando-se, assim, um processo que implica diretamente a construção da textualidade.

Quando realizada a partir de expressões referenciais, a anáfora pode ser estabelecida a partir de diversas estruturas linguísticas, como pronomes, sintagmas adverbiais, sintagmas nominais, etc. (CAVALCANTE; CUSTÓDIO FILHO; BRITO, 2014). Na figura 2, o referente homologado em "aquela floresta" é retomado pela locução prepositiva contraída "nela". Essa retomada funciona como um elemento coesivo, na medida em que evita repetições no texto, mas também contribui para organizá-lo e orientar a construção de sentidos.

Além das expressões linguísticas mais explícitas, as elipses também podem marcar uma relação anafórica. É o que ocorre com o pronome elíptico "nós” em “ø vamos tacar fogo nela" que retoma os referentes "Rose" e "Jack". No entanto, diferentemente da anáfora "nela", essa elipse não retoma uma unidade linguística, mas os referentes homologados na semiose visual do texto; os dois personagens que aparecem na cena do filme aludida na produção do meme.

Abrindo um parêntese na apresentação dos processos anafóricos, é válido salientar que essa intrínseca relação de sentidos estabelecida entre as semioses que compõem o texto, que se estabelece pelos recursos referenciais, aponta para a necessidade de uma visão de texto que considere as diversas formas de semiotização dos sentidos e não somente os elementos linguísticos. Uma análise orientada por uma visão verbocêntrica de texto, como criticam Cavalcante e Custódio Filho (2010), que focasse apenas na semiose linguística desse meme, 
não daria conta de sua textualidade, uma vez que a construção dos sentidos (e assim da

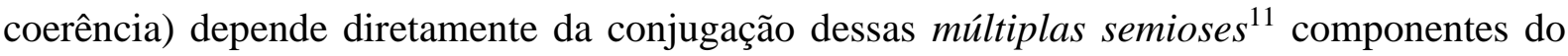
texto.

Mas, retomando a discussão, cumpre dizer que há tipos diferentes de anáfora, que variam mediante o modo como retomam um objeto de discurso. Pode ser direta (ou correferencial), quando retoma um referente já homologado no texto, ou indireta, que ocorre quando há a "apresentação de um novo referente como se este já fosse conhecido" (CUSTÓDIO FILHO, 2011, p. 131). A anáfora indireta é o tipo de relação anafórica na qual um referente não retoma outro anteriormente homologado, mas remete a uma série de referentes ou informações dispostas - ou que podem ser inferidas - no contexto. Vejamos o trecho de uma notícia:

Figura 3 - Queimadas na Austrália (trecho de notícia)

A combinação de secas e ondas de calor recordes, efeitos das
mudanças climáticas, foram o combustível que faltava para
queimadas sem precedentes no país
A Austrália enfrenta, desde setembro de 2019 , um evento de queimadas sem
precedentes, que já consumiu 6,3 milhões de hectares, matou 23 pessoas e
um número incalculável de animais. Com focos especialmente concentrados
na região leste da Austrália, onde a situação mais grave é no estado de Nova
Gales do Sul, que fica no sudeste da ilha, o fogo já destruiu mais de 2.500
prédios em todo o país - sendo que 1.500 apenas em Nova Gales do Sul.

Fonte: Portal Greenpeace. Disponível em: https://www.greenpeace.org/brasil/blog/incendios-na-australiatragedia-incontrolavel/. Acesso em 10 de jan. de 2020.

Nesse trecho de uma notícia publicada no site do Greenpeace sobre os incêndios ocorridos na Austrália no ano de 2019, dentre as muitas anáforas presentes, podemos destacar "tragédia incontrolável", que aparece no título do texto para retomar "incêndios na Austrália". Essa anáfora é considerada direta ou correferencial porque retoma um referente específico homologado no texto, conforme discutimos. Como exemplo de anáfora indireta, temos o referente "fogo" que aparece retomando não um referente específico homologado

\footnotetext{
${ }^{11}$ Desse modo, destacamos a importância de se conceber o texto para além de um horizonte linguístico, o que só é possível a partir de um olhar ampliado que contemple os diversos elementos (imagéticos, visuais, sonoros, gráficos, táteis etc.) que possam constituir sua parte material, bem como os vários parâmetros textuais pelos quais se constitui a unidade de sentido (referenciação, intertextualidades, plano de textos e sequências textuais, etc.), isto é, a textualidade, como bem solicitam Cavalcante e Custódio Filho (2010) e Cavalcante et al (2019).
} 
anteriormente, mas uma rede de informações que emergem no texto a partir de diversos outros elementos. Nesse caso, "fogo" remete ao incêndio, às queimadas e à tragédia descrita, de modo que aparece no universo textual sem causar estranheza ao leitor, que o relaciona, a partir de inferências, com os demais elementos do texto.

Nesse processo de retomada de referentes, mais do que apenas referir um objeto de discurso já homologado, uma anáfora pode cumprir a função de recategorizá-lo. Veja-se que o referente "Incêndios na Austrália" não é simplesmente retomado pela expressão referencial "tragédia incontrolável", mas é enquadrado em uma nova categoria; ganha um novo status no texto. Tem-se, ai, o processo anafórico de recategorização, que é de suma importância para a progressão temática dos textos, para a coesão (porque evita repetições não funcionais e estabelece elos) e, sobretudo, para a argumentatividade, uma vez que enquadrar determinado referente em uma determinada categoria é colocar sobre ele um ponto de vista específico (CAVALCANTE; CUSTÓDIO FILHO; BRITO, 2014). Desse modo, a recategorização, conforme atestam Ciulla e Matos (2016), cumpre sempre uma função avaliativo-argumentativa no texto.

Cumpre dizer ainda que, no exemplo em questão, o novo enquadramento dado ao referente apreende-se de uma expressão nominal (tragédia incontrolável), no entanto, os elementos que estabelecem esse processo podem ser de diversas ordens semióticas (como se vê em Lima, 2017) e, inclusive, a recategorização pode ocorrer sem que haja sequer menção de expressão referencial, como observado em Cavalcante (2012) e Custódio Filho (2011; 2014). Isso ficará mais claro na próxima seção, especialmente nas análises do segundo meme (figura $5)$.

Ademais, é preciso tratar sobre o processo de encapsulamento anafórico, que ocorre quando uma expressão referencial anafórica retoma não um, mas diversos referentes, resumindo-os ou "encapsulando-os". No texto acima, exemplifica-se o encapsulamento pela expressão "o combustível" que retoma e encapsula os referentes "secas", "ondas de calor" e "efeitos da mudança climática" para relacioná-los aos incêndios na Austrália, classificando-os hiponimicamente como elementos desencadeadores da tragédia ambiental.

Todos esses processos de introdução, retomada, atualização e (re)categorização de referentes configuram a progressão referencial de um texto, que diz respeito ao modo como os objetos de discurso (referentes) surgem e são tecidos no universo textual/discursivo. Sobre isso, é importante dizer, conforme Matos (2018), que os modos de homologação e progressão dos referentes de um texto não se dão de modo linear, no qual um referente emerge de uma expressão referencial e posteriormente é remetido por outras expressões, como uma cadeia, mas 
de modo mais dinâmico e interativo, no qual referentes diversos homologam-se e são (re)categorizados em interdependência, configurando o que a autora chama de redes referenciais. Para Matos (2018, p. 93):

[...] as redes referenciais são entrelaçamentos de sentidos na construção dos referentes, os quais mantêm uma diversidade de relações entre si e que se adaptam, funcionalmente, aos modos de constituição dos textos. [...] tais redes são formadas por nódulos ativados pelo contexto, estabelecendo uma série de associações de várias naturezas, funcionando como links, ou modos de conexões entre os referentes, os quais são todos interligados na construção e manutenção da coerência.

Trazer a noção de redes referenciais para este trabalho é de extrema importância, uma vez que, além de considerar o contexto como fator importante para a interpretação dos referentes, possibilita situar o arranjo dos elementos cotextuais verbais e imagéticos dispostos num plano de texto relativamente curto que é o do meme. Em síntese, a noção de rede nos parece muito produtiva para analisar produções como o meme, cuja organização textual se faz com maior abundância de implícitos decorrentes da natureza humorística deste texto e das condições em que é produzido e viralizado.

Ademais esses processos, a terceira categoria tomada nos estudos da referenciação é a dêixis, que é o processo referencial no qual se estabelecem referentes que solicitam informações do entorno enunciativo para que sejam compreendidos e efetivamente homologados ${ }^{12}$. Como já dito, não aprofundaremos, neste estudo, as considerações sobre os processos dêiticos, tendo em vista que nossos objetivos recaem somente sobre os processos anafóricos e de introdução referencial.

\section{(Re)construindo os referentes em memes verbo-visuais: uma tarefa não linear}

Levando em consideração alguns dos exemplos que apresentamos nas seções anteriores, já é possível perceber que a semiose imagética pode desempenhar um papel importante para a (re)construção dos referentes nos textos que conjugam linguagens ou semioses diversas. Discutiremos mais sobre esse assunto a partir da análise de como os referentes são (re)construídos em dois memes verbo-visuais coletados do site de redes sociais Instagram.

A coleta desses textos não se deu mediante critérios temáticos ou outros mais rígidos, uma vez que não buscamos quantificar os tipos de introdução referencial e anáfora mais

\footnotetext{
12 Por exemplo, em "Aqui tem feito frio", o termo "aqui" aponta para um determinado espaço que somente pode ser compreendido a partir de informações sobre o contexto enunciativo no qual o enunciado foi proferido: por quem, em que situação e onde foi dito. Assim, "aqui" configura-se como uma expressão dêitica.
} 
recorrentes. Cremos que, diante da complexidade e instabilidade composicional que esses textos apresentam no contexto virtual - os quais podem admitir configurações semióticas diferentes a depender das ferramentas disponíveis - seja mais prudente buscar perceber modos possíveis de construção e reconstrução dos referentes; de introdução e anáfora, não tendo a pretensão de estabelecer, a partir de análise quantitativa, os modos mais recorrentes de introdução e manutenção de referentes nos memes. Cientes disso, passamos à primeira análise.

Figura 4 - Brasil de 2016-2019

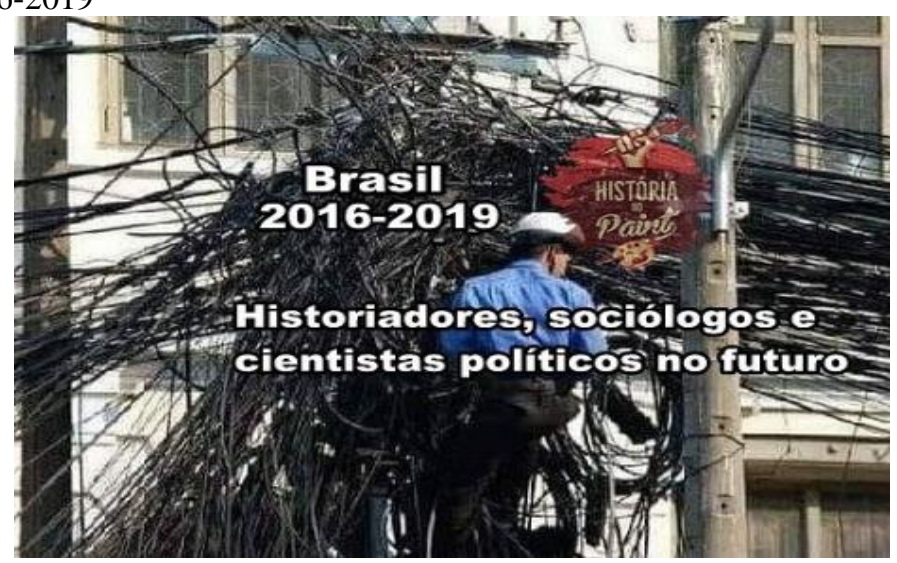

Fonte: https://www.instagram.com/p/B42WbvHnbHx/. Acesso em 09 de jan. de 2020.

A semiose imagética desse meme resulta da apropriação de uma foto sem origem certa e de difícil recuperação na qual se ilustra um profissional em contato com uma rede de alta tensão muito complexa e com vários fios entrelaçados (ao seu lado esquerdo). Do lado direito do homem, a rede de tensão aparece com menos entrelaces; está mais organizada. A partir disso, é possível inferir que o profissional esteja tentando realizar reparos nessa rede elétrica ou reorganizando a fiação comprometida.

A partir de um processo gráfico de "colagem", insere-se, em sobreposição à imagem da fiação embaraçada, a sequência "Brasil 2016-2019” e sobre a figura do homem, "Historiadores, sociólogos, e cientistas políticos no futuro". Essa conjunção de semioses e o modo como estão dispostas na superfície cotextual atribui a esse texto uma maior complexidade no que diz respeito à construção da referência. Isso se dá porque há licenciamento para que o leitor considere primeiro a imagem em detrimento aos elementos verbais (ou vice-versa) ou ainda que tome primeiro a sequência verbal inferior para depois tomar a superior, diferentemente do que ocorre canonicamente em textos majoritariamente verbais e extensos, como uma redação do Enem.

Por exemplo, se considerarmos, inicialmente, a expressão "Brasil 2016-2019" e a porção imagética que se associa a ela, será possível compreender que a expressão se refere metaforicamente à complexidade desse espaço temporal para o país (2016-2019). Nesse 
sentido, a rede elétrica densa e confusa recategorizaria metaforicamente, a partir de um elemento visual, o Brasil de 2016-2019 com um país cheio de problemas e complexidades. Convém dizer que Lima (2017) já tratou desse tipo de processo anafórico, o qual denominou de recategorização imagética, que ocorre justamente quando um referente passa a ser recategorizado por elementos visuais presentes no texto.

Esse mesmo processo ocorre com a expressão "Historiadores, sociólogos, e cientistas políticos no futuro" que é recategorizada pela imagem do eletricista. E mais que isso, essa recategorização propicia várias inferências sobre o referente Brasil de 2016-2019. Isso ocorre por meio da ativação dos conhecimentos enciclopédicos sobre o que são historiadores, sociólogos e cientistas políticos e qual o papel que desempenham. A partir da construção desses referentes, da mobilização dos conhecimentos sobre o fenômeno com os quais estes profissionais lidam (fatos históricos, sociais e políticos), como também as informações contextuais sobre o suporte no qual é veiculado o meme (página História no Paint, que divulga memes sobre diversos temas relacionados à história e política) é possível inferir que não se retoma propriamente o país (Brasil de 2016-2019) de modo amplo, ou simplesmente um espaço de tempo como um referente, mas o contexto sociopolítico brasileiro de 2016-2019.

Assim, é somente a partir da conjunção dessas diferentes informações em diferentes semioses, que convergem para compor o meme verbo-visual, que o referente em destaque pode ser (re)construído. E essa complexa conjugação de informações, que não se dá a partir de uma inserção de um referente e posterior retomada, torna difícil a tarefa de definir onde a partir de que materialidade o referente é introduzido e onde, especificamente, passa a ser recategorizado. Seria mais coerente dizer que um se (re)constrói em uma dinâmica relação com outros, formando uma interconexão em redes referenciais (MATOS, 2018), e que os referentes não estão antes ou depois um do outro, mas dispostos no texto à espera do olhar atento do interlocutor, para que os retome, relacione-os e (re)construa-os.

Esse tipo de recategorização (imagética) ocorre também no meme seguinte (figura 5). O texto é composto pelo agrupamento de duas imagens nas quais se ilustra a figura de um gigante de pedra, o qual se ergue (imagem superior) e passa a andar (imagem inferior). Essa porção imagética do texto faz alusão a um comercial ${ }^{13}$ da empresa escocesa de bebidas Johnnie Walker, em que um gigante de pedra emerge e anda pela cidade do Rio de Janeiro.

\footnotetext{
${ }^{13}$ Disponível em: https://www.youtube.com/watch?v=DuW1aj2s9uw. Acesso em 12 de jan. de 2020.
} 
Figura 5 - Caramba, o gigante acordou...

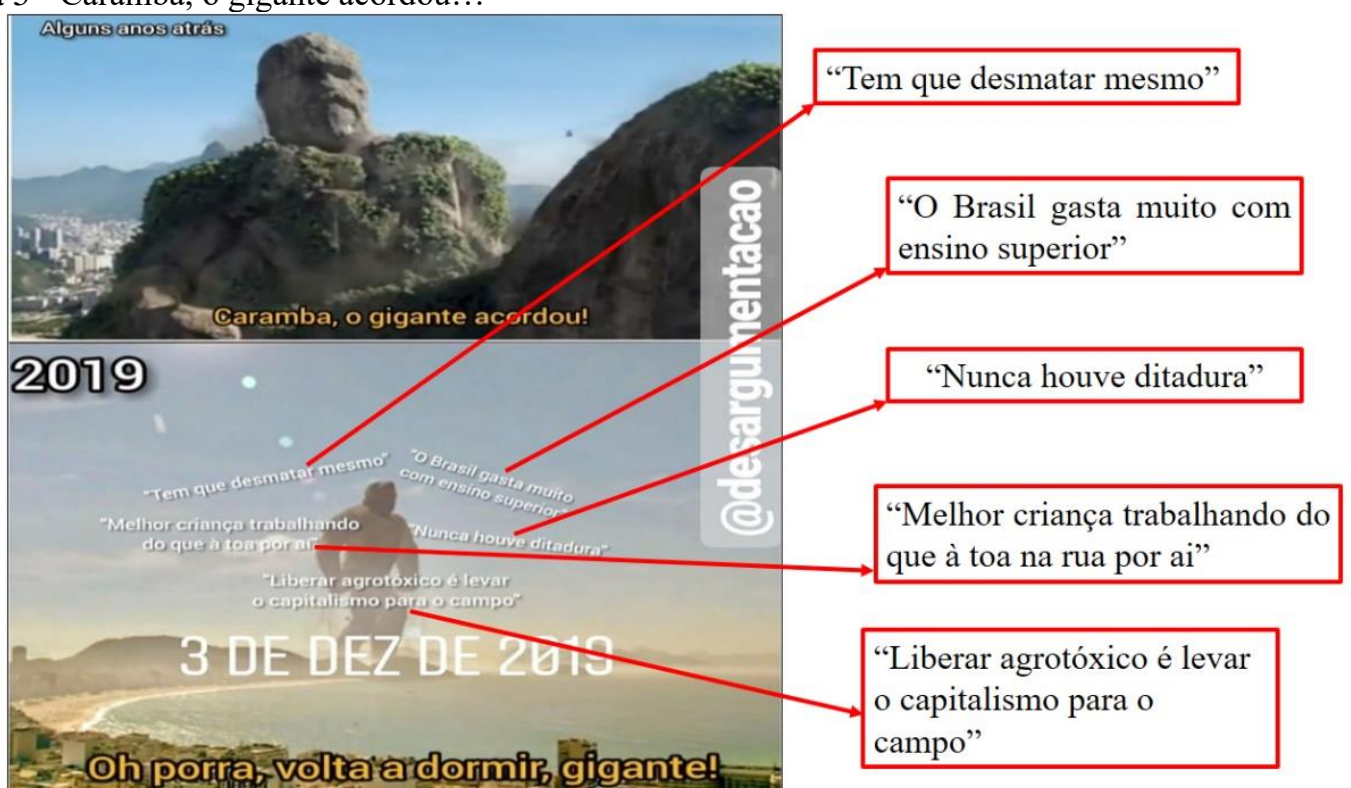

Fonte: https://www.instagram.com/p/B5sM36RFO36/?igshid=m448nyxwcjdf. Acesso em 09 de jan. de 2020.

É importante dizer que esse comercial em forma de vídeo foi originalmente produzido pela empresa em 2011, mas ficou famoso durante os protestos contra o aumento de tarifas do transporte coletivo público na cidade de São Paulo, em 2013. Na ocasião, o vídeo foi parodiado por grupos políticos que associaram a figura do gigante às diversas manifestações que estavam ocorrendo no momento. Ele seria a representação da população que estava "adormecida" diante dos problemas socioeconômicos da época, mas que "acordou" ao sair às ruas para se manifestar.

Mas, retornando à descrição cotextual do meme, tem-se agregada à imagem superior a expressão dêitica "alguns anos atrás" e, além dela, "Caramba, o gigante acordou", expressão que estabelece, junto à semiose imagética, relações intertextuais com os vídeos produzidos anteriormente (textos-fonte). No entanto, esse gigante passa a ser recategorizado por meio do que se coloca na imagem inferior do meme, principalmente a partir das pistas deixadas pelas afirmações inseridas em forma de citação ao redor de sua silhueta.

A partir das citações "O Brasil gasta muito com o ensino superior", "tem que desmatar mesmo", "nunca houve ditadura" e as demais destacadas acima vai-se construindo um perfil ideológico comum aos sujeitos que corroboram com esses dizeres, os quais estariam recategorizados na figura do gigante, ou seja, sujeitos conservadores. Essa construção se dá por meio de inferências e pela mobilização de conhecimentos de ordem sociopolítica e histórica por parte do leitor. Com a construção desse perfil ideológico e a partir da retomada do que simbolizava a figura do gigante em outros textos, efetiva-se a construção do referente população conservadora brasileira. 
Interessante notar que a homologação do referente "população brasileira" só é possível a partir da consideração da figura do gigante e da porção verbal na imagem inferior, elementos que, ao mesmo tempo recategorizam e ajudam a homologar o referente instaurado nesse contexto pela figura da imagem superior. Cumpre notar que a recategorização desse referente como "conservador" não se dá a partir de uma única expressão, mas por inferências sobre os intertextos mobilizados e pela mobilização de vários conhecimentos. Temos, nesse caso, o que Custódio Filho (2011) chama de recategorização sem menção referencial, que é um tipo de processo que acontece quando um referente se transforma no texto sem que haja uma expressão referencial anafórica específica responsável por essa transformação.

Assim como no meme anterior, percebe-se que a construção dos referentes não se dá de modo linear, no qual homologa-se um referente que em seguida é retomado/recategorizado. Ao contrário, a construção demanda do interlocutor uma interação mais dinâmica que contemple o texto em sua inteireza e que considere a inter-relação de todos os elementos quase que de modo síncrono. Desse modo, confirmamos e reiteramos o que postula Custódio Filho (2011, p. 153154) sobre o caráter não linear da construção dos referentes:

Quando se trata de construir referentes em um texto, o caminho seguido não precisa, necessariamente, obedecer à linearidade do enunciado, ou seja, não precisa, apenas, reconhecer as relações entre um antecedente e seus diversos anafóricos, na ordem em que aparecem. O trabalho interpretativo é muito mais difuso, feito de idas e vindas, de maneira que tanto o enunciador quanto os interlocutores (sabedores de que é assim que as coisas são) articulam suas ações via texto com base nesse parâmetro.

Esse modo difuso e de "idas e vindas" que configura o processo interpretativo, como pontua o autor, fica evidente tanto nesse meme quanto no anteriormente analisado, na medida em que os textos solicitam do leitor uma interação mais dinâmica, que relacione o que se apresenta nas diversas semioses e se articule informações e conhecimentos acionados por um e outro referente para que os sentidos possam ser efetivamente construídos.

Assim sendo, compreendemos que, nesses memes, a construção e reconstrução dos referentes se dá de modo não linear, na qual um referente se constrói e é reconstruído em diálogo com outros, apresentando pistas que implicam a homologação dos demais e dependendo de informações engatilhadas por eles para ser efetivamente construído. Constata-se, assim, que a tessitura referencial dos memes se constitui muito mais em forma de rede do que de cadeia, validando, desse modo, a noção de redes referenciais proposta por Matos (2018) bem como sua importância para concepção e análise dos processos de referenciação. 


\section{Considerações Finais}

Neste trabalho, lançamos foco sobre os processos de referenciação, especificamente, as anáforas e a introdução referencial em textos que denominamos aqui como memes verbovisuais a fim de propor uma reflexão sobre a dinâmica de construção e reconstrução dos referentes nesses textos.

A partir dos dois textos analisados, percebemos que essa (re)construção dos referentes se deu de modo não linear e dentro de uma progressão referencial não em forma de cadeia, mas de rede (MATOS, 2018), uma vez que a homologação e categorização não estavam restritas a uma expressão referencial específica, mas dependiam da conjugação de diversos elementos, tanto verbais quanto imagéticos, além da associação entre diversas "pistas" dispostas no (con)texto. Isso ficou mais saliente no segundo meme (figura 5), tendo em vista que a compreensão de que o gigante de pedra recategoriza a população conservadora brasileira somente se efetiva na inter-relação entre a primeira representação do gigante (na imagem superior do meme), da segunda representação (imagem inferior do meme) e do intertexto mobilizado pelas citações inseridas.

Acreditamos que esse modo de (re)construção dos referentes se dê por conta do plano de texto relativamente curto dos memes verbo-visuais, o qual apresenta "de uma só vez" todo o corpo do texto e, geralmente, a partir de um quadro imagético com poucos elementos de ordem linguística. Esse modo de disposição composicional propicia uma relação de interação mais fluida e dinâmica entre texto e leitor, bem como torna complexa a tarefa de definir a partir de que elemento, especificamente, um referente é homologado e quando, exatamente, passa a ser retomado.

Assim, tendo constatado que a (re)construção dos referentes nesses memes se deu de modo não linear e em uma tessitura de progressão sob a forma de rede, concluímos, consoante Custódio Filho (2011), que uma análise que se prenda às expressões referenciais de introdução e retomada referencial, sem considerar a complexidade característica dos processos de referenciação, em uma perspectiva sociocognitivo-discursiva, é insuficiente para explicar a dinâmica referencial dos textos. E quando observamos textos com um plano composicional relativamente curto e construídos a partir múltiplas semioses, como os memes aqui tratados, essa insuficiência torna-se ainda mais saliente.

Finalmente, pontuamos a necessidade de mais e maiores estudos que investiguem os processos de referenciação em textos de natureza multissemiótica e que levem em conta a complexidade que esses processos possam apresentar nos mais diversos textos. 


\section{Referências}

BAKHTIN, M, M. Estética da criação verbal. São Paulo: Martins Fontes, 2003.

BARROS, A. C. A compreensão dos memes através dos comentários do Facebook. 2016. 175 f. Dissertação (Mestrado) - Programa de Pós-Graduação em Letras da Universidade Federal de Pernambuco, Recife, 2016.

CAPISTRANO JÚNIOR, R. Referenciação e humor em tiras do Gatão de meia-idade, de Miguel Paiva. 2012. 138 f. Tese (Doutorado em Língua Portuguesa). Pontifícia Universidade Católica de São Paulo, São Paulo, 2012.

CARVALHO, A. P. L. Sobre intertextualidades estritas e amplas. 2018. $133 \mathrm{f}$. Tese (Doutorado em Linguística) - Programa de Pós-graduação em Linguística, Universidade Federal do Ceará, Fortaleza, 2018.

CAVALCANTE, M. M. et al. O texto e suas propriedades: definindo perspectivas para análise. Revista (Con)Textos Linguísticos, Vitória, v. 13, n. 25, p. 25-39. 2019.

CAVALCANTE, M. M. Referenciação: sobre coisas ditas e não ditas. Fortaleza: Edições UFC, 2011.

CAVALCANTE, M. M.; CUSTÓDIO FILHO, V. Revisitando o estatuto do texto. Revista do GELNE, Piauí, v. 12, n. 2, p. 56-71. 2010.

CAVAlCANTE, M. M.; CUSTÓDIO FILHO, V.; BRITO, M. A. P. Coerência, referenciação e ensino. São Paulo: Cortez, 2014.

CAVALCANTE, M. M.; OLIVEIRA, R. O recurso aos memes em diferentes padrões de gêneros à luz da Linguística Textual. Desenredo, v. 15, n. 1, p. 8-23. 2019.

CIULLA, A.; MATOS, J. G. Os processos de recategorização na construção avaliativoargumentativa do texto. Revista Virtual de Estudos da Linguagem - ReVEL, edição especial, v. 14, n. 12, p. 258-277, 2016.

CUSTÓDIO FILHO, V. Múltiplos fatores, distintas interações: esmiuçando o caráter heterogêneo da referenciação. 2011. 330 f. Tese (Doutorado em Linguística) - Programa de Pós-graduação em Linguística, Universidade Federal do Ceará, Fortaleza, 2011.

CUSTÓDIO FILHO, V. Análise da referenciação por meio de traços de significação. In: FIGUEIREDO, M. F. (Org.). Textos: sentidos, leituras e circulação. Franca: Unifran, 2014. p. 199-224.

DAWKINS, R. O Gene Egoísta. São Paulo: Companhia das Letras, 2007[1976].

LIMA NETO, V. Um estudo da emergência de gêneros no Facebook. 2014. 312 f. Tese (Doutorado em Linguística) - Programa de Pós-graduação em Linguística, Universidade Federal do Ceará, Fortaleza, 2014.

LIMA, S. C. Referenciação e multimodalidade: revisitando os processos de recategorização e encapsulamento. Revista das Letras, Fortaleza, v. 2, n. 36, p. 101-114, 2017. 
MARCUCHI, L. A. Atividades de referenciação, inferenciação e categorização na produção de sentido. In: FELTES, H. P. de M. (Org.). Produção de Sentido - Estudos

Transdisciplinares, São Paulo/Porto Alegre/Caxias: Annablume/Nova Prova/Educs, 2003. p. 239-262.

MATOS, J. G. As redes referenciais na construção de notas jornalísticas. 2018. 259 f. Tese (Doutorado em Linguística) - Universidade Federal do Ceará, Programa de Pósgraduação em Linguística, Fortaleza, 2018.

MONDADA, L. Construction des objets de discours et catégorisation: une epproche des processos de référenciation. Trad. Mônica Magalhães Cavalcante. Revista das Letras, Fortaleza, v. 1/2, n. 24, p. 118-130, jan./dez. 2002[1995].

MONDADA, L.; DUBOIS, D. Construção dos objetos de discurso e categorização: uma abordagem dos processos de referenciação. In: CAVALCANTE, M. M.; RODRIGUES, B. B.; CIULLA, A. (Orgs.). Referenciação. São Paulo: Contexto, 2003[1995]. p. 17-52.

PIMENTEL, R. L. Um estudo sobre hibridização e agrupamento de gêneros no Facebook. 2014. 116 f. Dissertação (Mestrado em Linguística) - Programa de Pós-graduação em Letras da Universidade Federal de Pernambuco, Recife, 2014.

RECUERO, R. Comunidades em redes sociais na internet: proposta de tipologia baseada em fotolog.com. 2006. 334 f. Tese (Doutorado em Comunicação e Informação) - Programa de Pós-graduação em Comunicação e Informação da Universidade Federal do Rio Grande do Sul, Porto Alegre, 2006.

SILVA, F. O. Formas e funções das introduções referenciais. 2013. 127 f. Tese (Doutorado em Linguística) - Programa de Pós-graduação em Linguística, Universidade Federal do Ceará, Fortaleza, 2013.

\section{Sobre os autores}

João Paulo Muniz da Silva (Orcid iD: https://orcid.org/0000-0003-0653-6554)

Mestrando (bolsista CAPES) no Programa de Pós-Graduação em Letras da Universidade Federal de Pernambuco (UFPE); graduado em Letras pela Universidade de Pernambuco (UPE) e membro do Grupo de Estudos do Texto (GESTO/UFPE/ CNPq).

Suzana Leite Cortez (Orcid iD: https://orcid.org/0000-0003-0983-0900)

Doutora e mestra em Linguística pela Universidade Estadual de Campinas (UNICAMP), com estágio doutoral na Université de Lyon 2 e graduada em Letras pela UFPE. É professora do Departamento de Letras e do Programa de Pós-Graduação em Letras da UFPE e líder do Grupo de Estudos do Texto (GESTO/UFPE/ CNPq).

Recebido em agosto de 2020.

Aprovado em setembro de 2020. 